\title{
Effect of the methylenetetrahydrofolate reductase gene C677T polymorphism on $C$-erbB-2 methylation status and its association with cancer
}

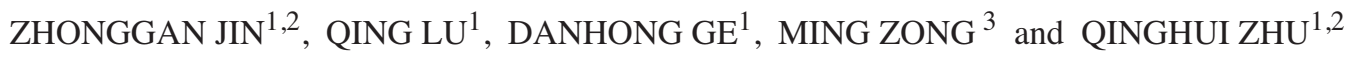 \\ ${ }^{1}$ Teaching Hospital of Jiangsu University, Shanghai People's Hospital of Putuo District, Shanghai 200060; \\ ${ }^{2}$ School of Preclinical Medicine and Medical Technology, Jiangsu University, Zhenjiang 212013; \\ ${ }^{3}$ Orient Hospital Affiliated to Tongji University, Shanghai 200120, P.R. China
}

Received September 30, 2008; Accepted December 3, 2008

DOI: $10.3892 / \mathrm{mmr} 00000097$

\begin{abstract}
Methylation abnormalities of cancer-related genes are recognized to play an important role in carcinogenesis. Methylenetetrahydrofolate reductase (MTHFR) regulates DNA methylation by affecting synthesis of S-adenosylmethionine, which is a universal methyl donor for methylation reactions. MTHFR gene polymorphisms that affect enzymatic activity may be associated with DNA methylation and cancer susceptibility. In the present study, we investigated the MTHFR C677T polymorphism in 247 cancer patients and 100 healthy subjects using PCR-RFLP, as well as the methylation status of the $\mathrm{CpG}$ island in the promoter region of the $C$-erbB-2 oncogene in 247 tumor and matched adjacent tissue samples using methylation-specific PCR. The results revealed that the methylation rate of the $C$-erbB-2 gene was significantly lower in the tumor tissues than in the matched adjacent tissues (43.3 vs. $69.2 \%, \mathrm{P}=0.000)$. No correlation was observed between the methylation patterns of $C$-erbB-2 in tumor tissues and the clinicopathological characteristics of the patients. The frequency of the MTHFR gene $677 \mathrm{~T}$ allele was significantly higher in cancer patients than in the healthy subjects, and the combined variant genotypes $(677 \mathrm{CT}+\mathrm{TT})$ significantly increased the risk of developing cancer $(\mathrm{OR}=1.619$, 95\% CI 1.012-2.588, $\mathrm{P}=0.043)$. Among the cancer patients, the methylation rate of the $C-e r b B-2$ gene was higher in individuals with the $\mathrm{CC}$ genotype than in those with the CT/TT genotype (50.0 vs. 39.4\%). This difference was not significant $(\mathrm{P}=0.103)$. However, a significant difference was found in patients with breast cancer $(\mathrm{P}=0.008)$. In conclusion, the $C$-erbB-2 promoter $\mathrm{CpG}$ island was hypomethylated in cancer patients, and the MTHFR $677 \mathrm{CT} / \mathrm{TT}$ genotype
\end{abstract}

Correspondence to: Dr Qinghui Zhu, Teaching Hospital of Jiangsu University, Shanghai People's Hospital of Putuo District, Shanghai 200060, P.R. China

E-mail: zhuqinghui47@hotmail.com

Key words: C-erbB-2, methylation, methylenetetrahydrofolate reductase, cancer increased the risk of developing the disease. Moreover, in breast cancer patients, the MTHFR gene C677T polymorphism had an effect on the methylation status of the $C-e r b B-2$ gene.

\section{Introduction}

DNA methylation of gene promoter $\mathrm{CpG}$ islands has been recognized as an important mechanism for the regulation of gene expression associated with the development and progression of various types of cancer $(1,2)$. DNA methylation depends on a sufficient supply of the methyl-group donor S-adenosylmethionine (SAM). The methyl-group used by SAM for methylation reactions is mainly derived from folate metabolism. One of the key enzymes regulating folate metabolism is methylenetetrahydrofolate reductase (MTHFR). MTHFR irreversibly catalyzes 5,10-methylenetetrahydrofolate to 5-methyltetrahydrofolate, which provides a methyl-group for the synthesis of methionine, a precursor of SAM $(3,4)$. Of the three common MTHFR polymorphisms (C677T, G1793A and A1298C), the C677T polymorphism, which results in an alanine for valine substitution, affects the thermolability and catalytic activities of MTHFR. The 677TT homozygote and 677CT heterozygote are considered to have about 30 and $65 \%$ of wild-type MTHFR enzymatic activity, respectively $(5,6)$. The relation of the C677T polymorphism to various types of cancer has been investigated, but with discrepant results (7-15).

To date, many studies have reported on the CpG methylation status of tumor suppressor genes. Several researchers have investigated its association with MTHFR polymorphisms (16-18), but provided little information regarding oncogene methylation. The $C$-erbB-2 oncogene, also known Her2/neu and located on $17 \mathrm{q} 21$, encodes a $185-\mathrm{kDa}$ transmembrane glycoprotein (p185) that belongs to the epidermal growth factor receptor family. p185 has intrinsic tyrosine kinase activity, which results in ligand-independent activation leading to cell proliferation and malignant transformation through different signal conduction pathways (19). Many investigations have focused on the overexpression and/or amplification of the $C$-erbB-2 gene in cancer (20-23); however, only a few have reported on the methylation status of $C-e r b B-2$ in tumors $(24,25)$. At present, there are no reports on the correlation of 
MTHFR polymorphisms with the methylation of the $C$-erbB-2 gene. Here, we aimed to investigate the effect of the MTHFR C677T gene polymorphism on $C$-erbB-2 methylation status and its association with cancer.

The methylation status of the $C$-erbB-2 gene was examined in 247 malignant and matched non-neoplastic adjacent tissues from patients with various types of cancer using methylationspecific PCR (MSP) (26), and the MTHFR C677T polymorphism was investigated in 247 patients and 100 healthy subjects using PCR-based restriction fragment length polymorphism analysis (PCR-RFLP) (5).

\section{Materials and methods}

Sample collection. A total of $24710 \%$ formalin-fixed surgically resected tumor tissues and 247 paired non-neoplastic adjacent tissues from 247 patients with cancer were collected at the Teaching Hospital of Jiangsu University (Shanghai People's Hospital of Putuo District, Shanghai, P.R. China) and the First People's Hospital of Zhenjiang City (Jiangsu Province, P.R. China) between October 2006 and March 2008. The study was approved by the local ethics committee. The 247 patients were Han Mongolians (127 males, 120 females; average age 65 years, range 29-92) diagnosed with various types of cancer, including 24 esophageal, 82 gastric, 86 colorectal carcinomas, 14 lung and 41 breast cancers. Tumor staging was performed according to the International Union against Carcinoma (UICC) tumor-node-metastasis (TNM) classification (T1, 22; T2, 58; T3, 139; T4, 28). As a control, blood samples were obtained by venipuncture from 100 healthy subjects ( 58 males, 42 females; average age 53 years, range 42-65), collected at Jiangsu University (Zhenjiang City, Jiangsu Province, P.R. China) in EDTA vacutainers and stored at $-70^{\circ} \mathrm{C}$ until analysis.

DNA extraction. Tissues were macerated by PBS, $\mathrm{pH} 7.4$, for $1 \mathrm{~h}$, then transferred to fresh PBS for an additional $24 \mathrm{~h}$. The tissues were homogenated with TES buffer, and samples were placed in Eppendorf tubes with a freshly prepared SDS lysis buffer and proteinase $\mathrm{K}$ (Merck KGaA, Germany), then incubated for $30 \mathrm{~min}$ at $60^{\circ} \mathrm{C}, 7 \mathrm{~h}$ at $55^{\circ} \mathrm{C}$ and overnight at $37^{\circ} \mathrm{C}$. Genomic DNA was extracted by the standard phenol: chloroform:isoamyl:alcohol protocol. The genomic DNA of the blood samples was extracted using the Puregene DNA Purification Kit (Gentra, USA) according to the manufacturer's protocol.

Methylation-specific PCR analysis. Genomic DNA (4 $\mu \mathrm{g})$ was converted by bisulfite treatment using the $\mathrm{CpGenome}^{\mathrm{TM}}$ DNA Modification Kit (Chemicon, USA). DNA was quantified using the RNA/DNA Calculator and stored at $-30^{\circ} \mathrm{C}$. The primer sequences for the wild-type, methylated and unmethylated $C$-erbB-2 gene (NT_010755) promoter were designed using Methyl Primer Express Software version 1.0 (Applied Biosystems, USA) and Oligo 6.0 (Molecular Biology Insights, USA), and synthesized by Shanghai Biotechnology Engineering (SBE, P.R. China). In order to confirm the effect of bisulfite treatment, DNA was amplified with wild-type primer before and after bisulfite modification. The primer sequences for the wild-type promoter (reaction) were sense
5'-CCA GAC TTG TTG GAA TGC-3' and antisense 5'-AAG AGG GCG AGG AGG AG-3', used to amplify a 352-bp product $(-205$ to +147$)$. Amplifications were performed in a PT-150 type Minicycler (MJ Research, USA) in a 20- $\mu 1$ volume reaction mixture containing $200 \mathrm{ng}$ DNA, $2 \mu 1$ 10X PCR buffer, $1 \mu \mathrm{ldNTP}$ (10 mmol/l), $3 \mu 1 \mathrm{Mg}^{2+}(25 \mathrm{mmol} / \mathrm{l})$, $1 \mu \mathrm{l}$ of each primer $(20 \mathrm{pmol} / \mu \mathrm{l})$ and $0.5 \mu \mathrm{l}$ Taq DNA polymerase $(5 \mathrm{U} / \mu 1)(\mathrm{SBE})$. PCR conditions were as follows: $95^{\circ} \mathrm{C}$ for $5 \mathrm{~min}$ followed by 35 cycles of denaturation at $95^{\circ} \mathrm{C}$ for $30 \mathrm{sec}$, annealing at $58^{\circ} \mathrm{C}$ for $30 \mathrm{sec}$ and extension at $72^{\circ} \mathrm{C}$ for $45 \mathrm{sec}$, and finally a final extension at $72^{\circ} \mathrm{C}$ for $5 \mathrm{~min}$. PCR products were electrophoresed on $1.5 \%$ agarose gel (Bio Basic, Canada) with ethidium bromide and visualized under ultraviolet illumination. DNA that could only be amplified by wild-type primers before but not after bisulfite treatment was amplified with methylated and unmethylated primers as follows: the primer sequences of $C-e r b B-2$ for the methylated promoter were sense 5'-TTT TAC GGG GTT TTT TAT TGC-3' and antisense 5'-TAA TAC TCA CTA CGA CTC CGA CC-3', generating a 120-bp product $(-119$ to +1$)$; and for the unmethylated promoter sense 5'-TTT TTA TGG GGT TTT TTA TTG T-3' and antisense 5'-ATA ATA CTC ACT ACA ACT CCA ACC-3', generating a 122-bp product $(-120$ to +2$)$. All bisulfite-modified DNA samples were amplified by PCR in a $20-\mu 1$ volume reaction mixture containing $200 \mathrm{ng}$ of bisulfite-modified DNA, with the remaining components identical to those used above. Reactions were hot-started at $95^{\circ} \mathrm{C}$ for $5 \mathrm{~min}$ and held at $90^{\circ} \mathrm{C}$ before the addition of Taq. PCR amplification was then carried out under the following conditions (with extension at $72^{\circ} \mathrm{C}$ for $30 \mathrm{sec}$ for all cycles): i) $95^{\circ} \mathrm{C}, 30 \mathrm{sec} ; 66^{\circ} \mathrm{C}, 30 \mathrm{sec}$; ii) $95^{\circ} \mathrm{C}, 30 \mathrm{sec} ; 64^{\circ} \mathrm{C}, 30 \mathrm{sec}$; iii) $95^{\circ} \mathrm{C}, 30 \mathrm{sec} ; 60^{\circ} \mathrm{C}, 30 \mathrm{sec}$; iv) $95^{\circ} \mathrm{C}, 30 \mathrm{sec} ; 60^{\circ} \mathrm{C}, 30 \mathrm{sec}$; v) $95^{\circ} \mathrm{C}, 30 \mathrm{sec} ; 58^{\circ} \mathrm{C}, 30 \mathrm{sec}$; (i-v, with 3 cycles respectively); vi) $90^{\circ} \mathrm{C}, 30 \mathrm{sec} ; 56^{\circ} \mathrm{C}, 30 \mathrm{sec}$; vii) $90^{\circ} \mathrm{C}, 30 \mathrm{sec} ; 54^{\circ} \mathrm{C}, 30 \mathrm{sec}$; viii) $90^{\circ} \mathrm{C}, 30 \mathrm{sec} ; 53^{\circ} \mathrm{C}, 30 \mathrm{sec}$; (vi-viii, with 4 cycles respectively); ix) $90^{\circ} \mathrm{C}, 30 \mathrm{sec} ; 52^{\circ} \mathrm{C}, 30 \mathrm{sec}, 20$ cycles followed by a final extension at $72^{\circ} \mathrm{C}$ for $5 \mathrm{~min}$. Each PCR product was separated by electrophoresis on $1.7 \%$ agarose gel with ethidium bromide. Blood DNA treated with $\mathrm{CpG}$ methylase M.SssI (New England Biolabs, USA) was used as the positive methylated control. When this positive methylated control was amplified by the methylated primers, DNA amplified by unmethylated but not methylated primers was used as the negative methylated (and positive unmethylated) control. DNA amplified by methylated but not unmethylated primers was used as a negative unmethylated control. Doubledistilled water was used instead of DNA as the blank control. Assessment of methylation status for the cases was as follows: those showing products amplified by methylated primers were considered methylated and those showing only products amplified by unmethylated primers were considered unmethylated $(27,28)$.

MTHFR polymorphism analysis. MTHFR polymorphisms were analyzed using PCR-RFLP with the HinfI restriction enzyme (Fermentas, Lithuania) described by Frosst et al (5). The 198-bp PCR product $(10 \mu \mathrm{l})$ was subjected to digestion with $20 \mathrm{U}$ HinfI overnight at $37^{\circ} \mathrm{C}$, followed by electrophoresis on $2.6 \%$ agarose gel with ethidium bromide. For the MTHFR C677T polymorphism, the wild-type C allele yielded a 198-bp 
Table I. Association of the MTHFR genotype and allele frequencies with clinicopathological characteristics in cancer patients and healthy control subjects.

\begin{tabular}{|c|c|c|c|c|c|c|c|}
\hline & \multirow[b]{2}{*}{ No. cases } & \multicolumn{2}{|c|}{ MTHFR genotype } & \multirow[b]{2}{*}{ P-value } & \multicolumn{2}{|c|}{ MTHFR allele frequencies } & \multirow[b]{2}{*}{ P-value } \\
\hline & & $\mathrm{TT}+\mathrm{CT}$ & $\mathrm{CC}$ & & $\mathrm{T}$ & $\mathrm{C}$ & \\
\hline Control subjects & 100 & 51 & 49 & 0.043 & 61 & 139 & 0.027 \\
\hline Cancer patients & 247 & 155 & 92 & & 195 & 299 & \\
\hline \multicolumn{8}{|l|}{ T-category } \\
\hline T1 & 21 & 12 & 9 & 0.887 & 14 & 28 & 0.457 \\
\hline $\mathrm{T} 2$ & 57 & 36 & 21 & & 44 & 70 & \\
\hline $\mathrm{T} 3$ & 140 & 90 & 50 & & 115 & 165 & \\
\hline $\mathrm{T} 4$ & 29 & 17 & 12 & & 22 & 36 & \\
\hline \multicolumn{8}{|c|}{ Lymph node metastasis } \\
\hline No & 120 & 76 & 44 & 0.855 & 96 & 144 & 0.816 \\
\hline $\mathrm{N}+$ & 127 & 79 & 48 & & 99 & 155 & \\
\hline \multicolumn{8}{|l|}{ Age } \\
\hline$<65$ & 117 & 62 & 55 & 0.893 & 76 & 158 & 0.301 \\
\hline$\geq 65$ & 130 & 70 & 60 & & 96 & 164 & \\
\hline \multicolumn{8}{|l|}{ Gender } \\
\hline Male & 127 & 82 & 45 & 0.544 & 108 & 146 & 0.154 \\
\hline Female & 120 & 73 & 47 & & 87 & 153 & \\
\hline
\end{tabular}

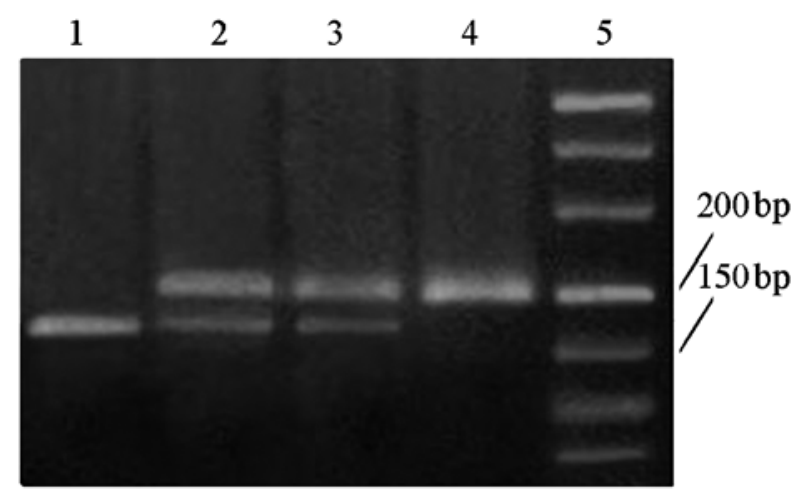

Figure 1. PCR-RFLP results for the MTHFR C677T polymorphism in cancer patients and controls. Lanes 1 and 4 respectively show TT and CC homozygotes for the C677T polymorphism; lanes 2 and 3 show CT heterozygotes for the C677T polymorphism in MTHFR. The 23-bp band could not be visualized after gel electrophoresis.

band and the mutant $\mathrm{T}$ allele yielded 175- and 23-bp bands. For quality control purposes, 50 samples were randomly selected for repeat genotyping. No discrepancies were found.

Statistical analysis. For statistical analysis, SPSS 10.0 for Windows (Chicago, IL, USA) was used. A P-value $<0.05$ was considered significant. To test the concordance of genotype frequencies with Hardy-Weinberg equilibrium, the $\chi^{2}$ test was used. The relationship between methylation status and the clinicopathological features of the cancer patients, as well as the effect of the MTHFR gene polymorphism on $C$-erbB-2 methylation status, was also examined using the $\chi^{2}$ test. To assess the relationship between the MTHFR genotype and the risk of cancer, the odds ratio (OR) and 95\% confidence interval (CI) were calculated using unconditional logistic regression.

\section{Results}

Genotyping of MTHFR in cancer patients and controls. The distribution of MTHFR genotypes in cancer patients and controls was in Hardy-Weinberg equilibrium (data not shown). A representative genotype analysis of MTHFR is shown in Fig. 1. Table I indicates that the frequency of the 677TT/CT genotype was $62.8 \%$ in cancer patients and $51 \%$ in controls. The respective allele frequencies of $\mathrm{C}$ and $\mathrm{T}$ were 60.5 and $39.5 \%$ in cancer patients and 69.5 and $30.5 \%$ in controls. The 677TT/CT genotype and $\mathrm{T}$ allele frequency were significantly higher in cancer patients than in controls $(\mathrm{P}=0.043$ and 0.027 , respectively). An association between genotypes or allele frequencies and the clinicopathological characteristics of the patients (gender, age, T-category, lymph node metastases) was not found. Compared with the CC genotype, the OR for the CT heterozygote was 1.494 (95\% CI 0.909-2.456, $\mathrm{P}=0.113$ ) and for the TT homozygote, 2.130 (95\% CI 0.982-4.623, $\mathrm{P}=0.052)$. The $677 \mathrm{TT} / \mathrm{CT}$ was associated with a 1.619 -fold (95\% CI 1.012-2.588, $\mathrm{P}=0.043)$ increased risk of developing cancer (Table II).

$C p G$ island methylation pattern of $C$-erbB-2. Promoter $\mathrm{CpG}$ island methylation of $C$-erbB-2 in the tumor and matched adjacent tissues was analyzed (Fig. 2). The methylation of the $C$-erbB-2 promoter was found in $43.3 \%$ (107/247) of tumor tissues and in $69.2 \%(171 / 247)$ of matched adjacent tissues. This difference was highly significant $(\mathrm{P}=0.000)$, indicating 
Table II. Association between the MTHFR C677T genotype in cancer patients and control subjects.

\begin{tabular}{lcccr}
\hline C677T & $\begin{array}{c}\text { No. patients }(\%) \\
(\mathrm{n}=247)\end{array}$ & $\begin{array}{c}\text { No. controls }(\%) \\
(\mathrm{n}=100)\end{array}$ & OR (95\% CI) & P-value \\
\hline $\mathrm{CC}$ a & $92(37.2)$ & $49(49)$ & & \\
$\mathrm{CT}$ & $115(46.6)$ & $41(41)$ & $1.494(0.909-2.456)$ & 0.113 \\
$\mathrm{TT}$ & $40(16.2)$ & $10(10)$ & $2.130(0.982-4.623)$ & 0.052 \\
$\mathrm{CT}+\mathrm{TT}$ & $155(62.8)$ & $51(51)$ & $1.619(1.012-2.588)$ & 0.043 \\
\hline
\end{tabular}

OR, odds ratio; CI, confidence interval. ${ }^{\mathrm{a}}$ The $\mathrm{CC}$ homozygote was used as the reference.

Table III. Correlation of $C$-erbB-2 methylation status with the clinicopathological characteristics of cancer patients.

\begin{tabular}{|c|c|c|c|c|}
\hline & No. patients & Methylated & Unmethylated & $\mathrm{P}$-value \\
\hline \multicolumn{5}{|l|}{ Gender } \\
\hline Male & 127 & 53 & 74 & \multirow[t]{2}{*}{0.605} \\
\hline Female & 120 & 54 & 66 & \\
\hline \multicolumn{5}{|l|}{ Age } \\
\hline$\geq 65$ & 130 & 61 & 69 & \multirow{2}{*}{0.228} \\
\hline$<65$ & 117 & 46 & 71 & \\
\hline \multicolumn{5}{|c|}{ T-category } \\
\hline $\mathrm{T} 1$ & 21 & 10 & 11 & \multirow[t]{4}{*}{0.133} \\
\hline $\mathrm{T} 2$ & 57 & 25 & 32 & \\
\hline $\mathrm{T} 3$ & 140 & 54 & 86 & \\
\hline $\mathrm{T} 4$ & 29 & 18 & 11 & \\
\hline \multicolumn{5}{|c|}{ Lymph node metastasis } \\
\hline No & 120 & 45 & 75 & \multirow[t]{2}{*}{0.073} \\
\hline $\mathrm{N}+$ & 127 & 62 & 65 & \\
\hline
\end{tabular}

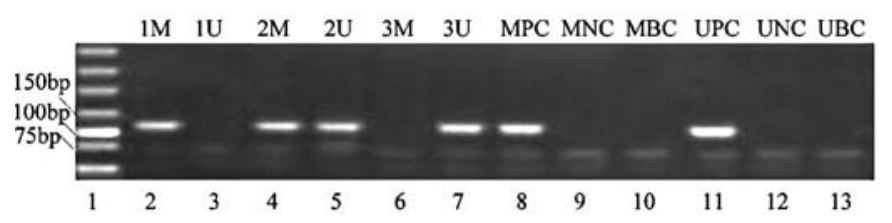

Figure 2. The methylation status of the $\mathrm{CpG}$ island in the promoter region of the $C$-erbB-2 gene in tumor tissues. Lane 1 shows the DNA marker; lanes 2-7 show the amplification products with methylated and unmethylated primers of $C$-erbB-2; lanes 8-10 respectively show the positive, negative and blank control of methylation; lanes 11-13 respectively show the positive, negative and blank control of unmethylation.

that the $C$-erbB-2 promoter $\mathrm{CpG}$ island was hypomethylated in tumor tissues. Moreover, there was no significant association between the methylation of $C$-erbB-2 in tumor tissues and the clinicopathological features of the patients, such as gender, age, T-category and lymph node status (Table III).

MTHFR gene genotypes versus $C$-erbB-2 promoter $C p G$ island methylation. No significant association was found between the MTHFR C677T polymorphism and the methylation status of the $C$-erbB-2 promoter $\mathrm{CpG}$ island in the cancer tissues. The methylation rate of the $C$-erbB-2 promoter $\mathrm{CpG}$ island was higher in individuals with the CC genotype than in those with the CT/TT genotype (50.0 vs. $39.4 \%$ ), but was without significance $(\mathrm{P}=0.103)$. The distribution difference of the $\mathrm{C}$ and $\mathrm{T}$ alleles was not significant between subjects with methylated and unmethylated $C$-erbB-2 promoter $\mathrm{CpG}$ islands $(\mathrm{P}=0.078)$. However, in breast cancer patients, the frequency of the $\mathrm{CC}$ genotype and $\mathrm{C}$ allele was significantly higher in patients with methylated $C$-erbB-2 promoter $\mathrm{CpG}$ islands than in patients with unmethylated $C$-erbB-2 promoter $\mathrm{CpG}$ islands $(\mathrm{P}=0.008$ and $\mathrm{P}=0.007$, respectively) (Table IV).

\section{Discussion}

In the present study, we examined whether MTHFR polymorphisms were associated with the methylation status of the $\mathrm{CpG}$ island in the $C$-erbB-2 gene promoter region. No statistically significant relationship was found between the C677T polymorphism and $C$-erbB-2 methylation status in the entire tumor sample. However, in breast cancer patients, a significant difference in distribution was found between the 
Table IV. Correlation between the MTHFR C677T polymorphism and CpG island methylation in the C-erbB-2 promoter region in breast cancer patients.

\begin{tabular}{|c|c|c|c|c|c|c|}
\hline & \multicolumn{2}{|c|}{ MTHFR genotype } & \multirow[b]{2}{*}{ P-value } & \multicolumn{2}{|c|}{ MTHFR allele frequencies } & \multirow[b]{2}{*}{ P-value } \\
\hline & $\mathrm{TT}+\mathrm{CT}$ & $\overline{\mathrm{CC}}$ & & $\mathrm{T}$ & $\mathrm{C}$ & \\
\hline Methylated & 7 & 13 & 0.008 & 7 & 33 & 0.007 \\
\hline Unmethylated & 16 & 5 & & 19 & 23 & \\
\hline
\end{tabular}

$\mathrm{C}$ and $\mathrm{T}$ alleles as well as the $\mathrm{CC}$ and $\mathrm{CT} / \mathrm{TT}$ genotypes in subjects with methylated and unmethylated $C$-erbB-2 promoter $\mathrm{CpG}$ islands $(\mathrm{P}=0.007$ and 0.008 , respectively). The C677T polymorphism affected the methylation pattern of the $C$-erbB-2 promoter $\mathrm{CpG}$ island, while the $\mathrm{CC}$ genotype and $\mathrm{C}$ allele increased its methylation rate in breast cancer patients.

In human malignancies, the $C$-erbB-2 gene plays an important role in the proliferation and transformation of cells, and promotes metastasis and the invasion of tumors (29). The amplification and overexpression of the $C$-erbB-2 gene has been reported in many types of tumors, such as gastric (20), colorectal (22) and breast (23) cancers. However, little attention $(24,25)$ has been directed to $C$-erbB-2 gene methylation, which is considered to be an important mechanism of gene expression regulation (30). We found that the methylation rate of the $C$-erbB-2 promoter was significantly lower in tumor $(\mathrm{n}=247)$ than in matched adjacent tissues $(\mathrm{P}=0.000)$, indicating the hypomethylation of the $C$-erbB-2 promoter $\mathrm{CpG}$ island in cancer patients. As hypomethylation was associated with the activation of genes, the activation of $C$-erbB-2 by promoter hypomethylation might contribute to the increased susceptibility of many solid tumors. Our results coincide with those of Hattori et al (24), who studied the demethylation of $\mathrm{CpG}$ sites in the promoter region of $C$-erbB-2 in ovarian cancer using methylation-sensitive restriction endonuclease-PCR. Using Southern blotting with methylation-sensitive restriction endonuclease enzyme, Holzmann et al (25) noted a difference in methylation status in gastric carcinoma $(\mathrm{n}=5)$, but not in colorectal cancer compared to mucosa samples $(n=17)$. To the contrary, in this study, we observed a difference in colorectal cancer but not in gastric cancer. This may be due to differences in sample size and/or detection methods. Moreover, the methylation status of $C$-erbB-2 in cancer tissues was not correlated with the clinicopathological characteristics of the patients.

MTHFR plays an important role in DNA methylation, synthesis and repair (31). Many studies have focused on the association between the MTHFR C677T polymorphism and susceptibility to cancer, with conflicting results. Some studies found that $677 \mathrm{~T}$ decreased the risk of childhood acute lymphocytic leukaemia (7), colorectal cancer (8), and lung cancer (9). In contrast, many researchers reported that $677 \mathrm{~T}$ was associated with an increased risk of cancer, such as breast cancer (10), gastric cancer (11), esophageal squamous cell carcinoma (12) and lung cancer (13). In addition, several researchers have suggested that there is no obvious association between the polymorphism and tumors $(14,15)$.

These conflicting results may be due to ethnic and regional differences, or to sample size. In our study, as a large sample for individual tumor types was not available, we evaluated the effect of C677T on a group of patients with several types of cancer, instead of conducting type-stratified analyses. Our findings indicate that the MTHFR 677 any $\mathrm{T}$ genotype significantly increased the risk of developing cancer $(\mathrm{OR}=1.619$, 95\% CI 1.012-2.588, $\mathrm{P}=0.043$ ). Moreover, this increased risk was dependent on $\mathrm{T}$ allele dose, with ORs of 1.494 (95\% CI 0.909-2.456) and 2.130 (95\% CI 0.982-4.623) for the CT and TT genotypes, respectively. These findings are in line with several previous reports (10-13).

Various studies in the literature have reported on the MTHFR gene C677T polymorphism in relation to promoter methylation of tumor suppressor genes. Of these, some failed to find a relationship between MTHFR C677T and gene promoter methylation $(16,32)$. In a Japanese population study, Oyama et al (18) observed that proximal colon cancers exhibiting the $\mathrm{CpG}$ island methylator phenotype were found significantly more frequently in patients with MTHFR genotypes of low rather than high enzymatic activity. In contrast, Kang et al (17) reported that the MTHFR 677CT genotype was associated with decreased promoter hypermethylation of $\mathrm{O}^{6}$-MGMT in 82 uterine cervical cancers. Our results, suggesting that the MTHFR C677T polymorphism has no effect on the methylation patterns of $C$-erbB-2 in tumor samples from various types of cancer, are similar to those of Clarizia et al (16) and Paz et al (32). However, one exception was noted in breast cancer patients; those with the MTHFR 677 CT/TT genotype exhibited a decreased $C$-erbB-2 promoter methylation rate. This discrepancy could be due to differences in tumor type. As previously reported, discrepant results have been obtained for different tumor types, even for the same gene. Siraj et al (33) demonstrated that there was no significant association between MTHFR variant genotypes and methylation of $\mathrm{O}^{6}$-MGMT in diffuse large B cell lymphoma. In contrast, Wang et al (34) reported that individuals carrying the $\mathrm{CT}$ or TT genotype had a higher frequency of $\mathrm{O}^{6}$-MGMT gene hypermethylation in esophageal squamous cell carcinoma tissues. These inconclusive results suggest that there are multiple other factors modulating methylation in addition to the MTHFR C677T polymorphism.

Various factors interact with and affect DNA methylation; of these, diet is the first in need of consideration, as a folate/ methyl-deficient diet leads to gene hypomethylation (35). Gene-specific promoter methylation was observed with increased serum folate and vitamin B12 levels, independently of the MTHFR 677 genotype (36). Moreover, C677T is not the only polymorphism of this gene; other polymorphisms, such as A1298C and G1793A, may affect the enzymatic activities and DNA methylation alone or in combination with the C677T polymorphism (6,37-39). Finally, we should bear in mind the 
crucial role of other enzyme genes involved in one-carbon metabolism. The methionine synthase (MS) A2756G polymorphism has been observed to decrease the methylation of $\mathrm{CpG}$ islands in tumor suppressor genes (32). Li et al (40) reported that the AA homozygote for the methylene tetrahydrofolate dehydrogenase (MTHFD1) G1958A polymorphism displayed more frequent hypermethylation of gene promoter region $\mathrm{CpG}$ islands in 227 cases of breast cancer.

However, the lack of information regarding folate levels and additional MTHFR polymorphisms, as well as other enzymes critical to the determination of SAM levels, limits our ability to provide a more comprehensive overview of the other factors affecting $C$-erbB-2 methylation through interaction with the MTHFR C677T polymorphism.

In conclusion, our findings suggest that the C677T polymorphism of the MTHFR gene is associated with individual susceptibility to cancer, and that the $C$-erbB-2 promoter $\mathrm{CpG}$ island is hypomethylated in cancer compared to matched non-neoplastic adjacent tissue. Moreover, the results indicate that the MTHFR C677T gene polymorphism has no effect on $C$-erbB-2 methylation patterns in tumor tissues, with the exception of breast cancer tissues. However, in addition to MTHFR polymorphisms, numerous factors may affect DNA methylation. Further research is therefore required to define the effects of various agents on $C-e r b B-2$ promoter methylation.

\section{Acknowledgements}

The authors thank Ya Yuan and Miao Chen for the sample collection, and Xianzhi Yang and Shuheng Hu for the DNA isolation. We are grateful to all those who kindly participated in this study. This work was supported by the Health Science Development Fund of Putuo District, Shanghai, P.R. China.

\section{References}

1. Baylin SB and Herman JG: DNA hypermethylation in tumorigenesis: epigenetics joins genetics. Trends Genet 16: 168-174, 2000.

2. Ehrlich M: DNA methylation in cancer: too much, but also too little. Oncogene 21: 5400-5413, 2002.

3. Choi SW and Mason JB: Folate and carcinogenesis: an integrated scheme. J Nutr 130: 129-132, 2000.

4. Friso S, Choi SW, Girelli D, et al: A common mutation in the 5,10-methylenetetrahydrofolate reductase gene affects genomic DNA methylation through an interaction with folate status. Proc Natl Acad Sci USA 99: 5606-5611, 2002.

5. Frosst P, Blom HJ, Milos R, et al: A candidate genetic risk factor for vascular disease: a common mutation in methylenetetrahydrofolate reductase. Nat Genet 10: 111-113, 1995.

6. Sharp L and Little J: Polymorphisms in genes involved in folate metabolism and colorectal neoplasia: a HuGE review. Am J Epidemiol 159: 423-443, 2004.

7. Franco RF, Simões BP, Tone LG, Gabellini SM, Zago MA and Falcão RP: The methylenetetrahydrofolate reductase C677T gene polymorphism decreases the risk of childhood acute lymphocytic leukaemia. Br J Haematol 115: 616-618, 2001.

8. Yin G, Kono S, Toyomura K, et al: Methylenetetrahydrofolate reductase C677T and A1298C polymorphisms and colorectal cancer: the Fukuoka Colorectal Cancer Study. Cancer Sci 95: 908-913, 2004

9. Suzuki T, Matsuo K, Hiraki A, et al: Impact of one-carbon metabolism-related gene polymorphisms on risk of lung cancer in Japan: a case control study. Carcinogenesis 28: 1718-1725, 2007.

10. Suzuki T, Matsuo K, Hirose K, et al: One-carbon metabolismrelated gene polymorphisms and risk of breast cancer. Carcinogenesis 29: 356-362, 2008.
11. Dong LM, Potter JD, White E, Ulrich CM, Cardon LR and Peters U: Genetic susceptibility to cancer: the role of polymorphisms in candidate genes. JAMA 299: 2423-2436, 2008.

12. Song C, Xing D, Tan W, Wei Q and Lin D: Methylenetetrahydrofolate reductase polymorphisms increase risk of esophageal squamous cell carcinoma in a Chinese population. Cancer Res 61: 3272-3275, 2001

13. Zhang XM, Miao XP, Tan W, Qu SN, Sun T, Zhou YF and Lin DX: Association between genetic polymorphisms in methylentetrahydrofolate reductase and risk of lung cancer. Zhongguo Yi Xue Ke Xue Yuan Xue Bao 27: 700-703, 2005.

14. Kim JK, Kim S, Han JH, et al: Polymorphisms of 5,10-methylenetetrahydrofolate reductase and risk of stomach cancer in a Korean population. Anticancer Res 25: 2249-2252, 2005.

15. Hekim N, Ergen A, Yaylim I, Yilmaz H, Zeybek U, Oztürk O and Isbir T: No association between methylenetetrahydrofolate reductase C677T polymorphism and breast cancer. Cell Biochem Funct 25: 115-117, 2007

16. Clarizia AD, Bastos-Rodrigues L, Pena HB, et al: Relationship of the methylenetetrahydrofolate reductase C677T polymorphism with microsatellite instability and promoter hypermethylation in sporadic colorectal cancer. Genet Mol Res 5: 315-322, 2006.

17. Kang S, Kim JW, Kang GH, Park NH, Song YS, Kang SB and Lee HP: Polymorphism in folate- and methionine-metabolizing enzyme and aberrant $\mathrm{CpG}$ island hypermethylation in uterine cervical cancer. Gynecol Oncol 96: 173-180, 2005.

18. Oyama K, Kawakami K, Maeda K, Ishiguro K and Watanabe G: The association between methylenetetrahydrofolate reductase polymorphism and promoter methylation in proximal colon cancer. Anticancer Res 24: 649-654, 2004.

19. Bargmann CI, Hung MC and Weinberg RA: The neu oncogene encodes an epidermal growth factor receptor-related protein. Nature 319: 226-230, 1986.

20. Kim MA, Jung EJ, Lee HS, Lee HE, Jeon YK, Yang HK and Kim WH: Evaluation of HER-2 gene status in gastric carcinoma using immunohistochemistry, fluorescence in situ hybridization, and real-time quantitative polymerase chain reaction. Hum Pathol 38: 1386-1393, 2007.

21. Wülfing C, von Struensee D, Bierer S, Bögemann M, Hertle L and Eltze E: Expression of Her2/neu in locally advanced bladder cancer: implication for a molecular targeted therapy. Aktuelle Urol 36: 423-429, 2005.

22. Tavangar SM, Shariftabrizi A and Soroush AR: Her-2/neu overexpression correlates with more advanced disease in Iranian colorectal cancer patients. Med Sci Monit 11: CR123-CR126, 2005.

23. Yu D and Hung MC: Overexpression of ErbB2 in cancer and ErbB2-targeting strategies. Oncogene 19: 6115-6121, 2000.

24. Hattori M, Sakamoto H, Satoh K and Yamamoto T: DNA demethylase is expressed in ovarian cancers and the expression correlates with demethylation of $\mathrm{CpG}$ sites in the promoter region of c-erbB-2 and survivin genes. Cancer Lett 169: 155-164, 2001.

25. Holzmann K, Welter C, Klein V, Pistorius G, Seitz G and Blin N: Tumor-specific methylation patterns of erbB2 (HER2/neu) sequences in gastro-intestinal cancer. Anticancer Res 12: 1013-1018, 1992

26. Herman JG, Graff JR, Myöhänen S, Nelkin BD and Baylin SB: Methylation-specific PCR: a novel PCR assay for methylation status of CpG islands. Proc Natl Acad Sci USA 93: 9821-9826, 1996.

27. Paredes J, Albergaria A, Oliveira JT, Jerónimo C, Milanezi F and Schmitt FC: P-cadherin overexpression is an indicator of clinical outcome in invasive breast carcinomas and is associated with CDH3 promoter hypomethylation. Clin Cancer Res 11: 5869-5877, 2005.

28. Oshimo Y, Nakayama H, Ito R, Kitadai Y, Yoshida K, Chayama K and Yasui W: Promoter methylation of cyclin D2 gene in gastric carcinoma. Int J Oncol 23: 1663-1670, 2003.

29. Akiyama T, Sudo C, Ogawara H, Toyoshima K and Yamamoto T: The product of the human c-erbB-2 gene: a 185-kilodalton glycoprotein with tyrosine kinase activity. Science 232: 1644-1646, 1986.

30. Robertson KD: DNA methylation and human disease. Nat Rev Genet 6: 597-610, 2005.

31. Bailey LB: Folate, methyl-related nutrients, alcohol, and the MTHFR $677 \mathrm{C} \rightarrow \mathrm{T}$ polymorphism affect cancer risk: intake recommendations. J Nutr 133: 3748S-3753S, 2003.

32. Paz MF, Avila S, Fraga MF, et al: Germ-line variants in methylgroup metabolism genes and susceptibility to DNA methylation in normal tissues and human primary tumors. Cancer 62: 4519-4524, 2002. 
33. Siraj AK, Ibrahim M, Al-Rasheed M, et al: Genetic polymorphisms of methylenetetrahydrofolate reductase and promoter methylation of MGMT and FHIT genes in diffuse large B cell lymphoma risk in Middle East. Ann Hematol 86: 887-895, 2007.

34. Wang J, Sasco AJ, Fu C, et al: Aberrant DNA methylation of P16, MGMT, and hMLH1 genes in combination with MTHFR C677T genetic polymorphism in esophageal squamous cell carcinoma. Cancer Epidemiol Biomarkers Prev 17: 118-125, 2008.

35. Kim YI: Folate and DNA methylation: a mechanistic link between folate deficiency and colorectal cancer? Cancer Epidemiol Biomarkers Prev 13: 511-519, 2004.

36. Mokarram P, Naghibalhossaini F, Saberi Firoozi M, et al: Methylenetetrahydrofolate reductase C677T genotype affects promoter methylation of tumor-specific genes in sporadic colorectal cancer through an interaction with folate/vitamin B12 status. World J Gastroenterol 14: 3662-3671, 2008.
37. Weisberg I, Tran P, Christensen B, Sibani S and Rozen R: A second genetic polymorphism in methylenetetrahydrofolate reductase (MTHFR) associated with decreased enzyme activity. Mol Genet Metab 64: 169-172, 1998.

38. Rady PL, Szucs S, Grady J, et al: Genetic polymorphisms of methylenetetrahydrofolate reductase (MTHFR) and methionine synthase reductase (MTRR) in ethnic populations in Texas; a report of a novel MTHFR polymorphic site, G1793A. Am J Med Genet 107: 162-168, 2002

39. Curtin K, Slattery ML, Ulrich CM, et al: Genetic polymorphisms in one-carbon metabolism: associations with $\mathrm{CpG}$ island methylator phenotype (CIMP) in colon cancer and the modifying effects of diet. Carcinogenesis 28: 1672-1679, 2007.

40. Li SY, Rong M and Iacopetta B: Germ-line variants in methylgroup metabolism genes and susceptibility to DNA methylation in human breast cancer. Oncol Rep 15: 221-225, 2006. 